\title{
People v. Murtishaw: Applying the Frye Test to Psychiatric Predictions of Dangerousness in Capital Cases
}

In California, a person convicted of first degree murder committed under statutorily enumerated "special circumstances"1 can be sentenced to death or to life imprisonment without possibility of parole. ${ }^{2}$ After the defendant has been found guilty and the trier of fact has determined that such special circumstances exist, a separate hearing is conducted to determine the defendant's sentence. ${ }^{3}$ In People v. Murtishaw ${ }^{4}$ the California Supreme Court held that in the penalty phase of a capital trial admission of a psychiatric prediction of dangerousness constitutes reversible error. In reaching its decision, the court noted that while such "expert" predictions are exceptionally unreliable, they can be highly prejudicial to the defendant. Moreover, the court argued, such predictions have hittle relevance to the statutorily defined factors that are supposed to guide the trier of fact in determining whether to impose the death sentence.

Although the Supreme Court reversed the death sentence because of the admission of the psychiatric predictions of dangerousness, the court did not create an absolute bar to such predictions. Instead, the court held that they would be admissable during the penalty phase of a capital trial if a party in a particular case could show that they were rehable. The court suggested two instances in which the required level of rehability might be established: 1) when the defendant has had a long-term relationship with the psychiatrist offering the prediction, and 2) when the defendant has "a long-continued pattern of criminal vio-

1. Cal. Penal Code $\$ 190.2$ (West Supp. 1982). Special circumstances include, inter alia, intentional inurder for financial gain, $i d . \$ 190.2(\mathrm{a})(1)$, and conviction in the same proceeding of more than one inurder, id. $\$ 190.2(a)(3)$.

2. Id. $\$ 190.3$.

3. Id. $\S 190.1$. Generally, the same jury that decided the issue of guilt will sit during the penalty phase. See id. $\S 19.4$ (c). A different jury will be impanelled if the jury is unable to reach a unanimous verdict that all the charged special circumstances are not true. This new jury will determine the special circumstances charges, and then, if necessary, determine penalty. Id. \$ 190.4(a). Additionally, if the defendant is found guilty by the court sitting without a jury, the trier of fact in the penalty phase will be a jury unless waived by both the defendant and the people. Id. \&190.4(b).

4. 29 Cal. 3d 733, 631 P.2d 446, 175 Cal. Rptr. 738 (1981) (6-1 decision; Tobriner, J.), cert. denied, 50 U.S.L.W. 3591 (U.S. Jan. 25, 1982). 
lence such that any knowledgeable psychiatrist could anticipate future violence."s

This Note argues that the California Supreme Court properly reversed the sentence of death because of the trial court's admission of an expert prediction of dangerousness during the penalty phase of the trial. The court, however, erred in suggesting two possible exceptions to its rule. Part I outlines the facts of Murtishaw. Part II presents the legal antecedents to Murtishaw. Part III argues that admission of expert predictions of dangerousness during the penalty phase of a capital trial threatens the reliability of the capital sentencing determination and thus the assurance that the death penalty, when given, is the appropriate sentence. Moreover, $\mathrm{m}$ view of this threat, the speculative nature of the expert testimony sliould go to its admissibility ratlier than its weight. Next, it is argued that an expert prediction should not be admissible im either of the imstances im whicl the court suggested sucl1 predictions may be more reliable. Part IV contends that imstead of announcing a new rule and two vaguely defined exceptions, the court should have held that expert predictions of dangerousness will be madmissible in the penalty pliase of a capital trial until they meet the Frye test for the admissibility of scientific evidence.

\section{I \\ The CASe \\ A. The Facts}

On April 9, 1978, David Leslie Murtisliaw and his brother-m-law went target shooting in the Mojave Desert. After their car broke down, they chanced upon four students making a movie for a college film class. The students agreed to give Murtishaw and his compamion a ride into town after the filming was finished. At the end of the day, while the students were preparing to leave, Murtishaw imexplicably began shooting at them. One student escaped, but the other three died as a result of the attack. A jury found Murtishaw guilty of three counts of first degree murder and in addition found the special circumstance of multiple murder. ${ }^{6}$

Before his trial, Murtishaw was examined for four lours by a court-appoimted psychopharmacologist to determine whether lie liad been under the influence of drugs at the time of the murders. At the penalty phase of the trial, the psychopharinacologist was called to testify as to the likelihood of Murtishaw's-committimg violent acts in the

\footnotetext{
5. Id. at 774,631 P.2d at 470,175 Cal. Rptr. at 762 .

6. Id. at $740-41,631$ P.2d at 449,175 Cal. Rptr. at 741 . Defendant was also found guilty of one count of assault with intent to commit inurder.
} 
future. He stated that Murtishaw "will continue to be a violent assaultive and combative individual . . . in a prison . . . because of his latent rage and hostility and violence . . . [ [H] could show the same types of homicidal tendencies that he has shown in the past, with no ability to morally or physically constram himself . . ."7 After three days of deliberations, the jury sentenced Murtishaw to death.

\section{B. The Opinions}

The California Supreme Court affirmed Murtishaw's conviction, but reversed the death sentence solely on the basis of the admission of the prediction of dangerousness. ${ }^{8}$ The majority cited numerous studies demonstratimg that psychiatric predictions of dangerousness constantly overpredict violence and thus have hittle reliability. ${ }^{9}$ The majority then presented two reasons for rejecting the argument that the unreliability and inaccuracy of such predictions should affect the weight of the testimony rather than its admissibility. First, the death penalty is unique in its severity, so greater reliability in sentencing is required than for imprisonment or civil commitment. ${ }^{10}$ Second, the applicable statute, former Penal Code section 190.3, ${ }^{11}$ did not require the trier of fact to assess the defendant's dangerousness. In contrast, psychiatric predictions of dangerousness were admitted in noncapital cases because the applicable statute required such an assessment. ${ }^{12}$ The court concluded that, while a psychiatric prediction of dangerousness was arguably admissible under forner section 190.3 as a matter relevant to aggravation, its probative value was outweighed by its prejudicial impact. ${ }^{13}$

Justice Richardson's dissent forcefully reasoned that a defendant's dangerousness was relevant to former section 190.3, since that section provided that evidence was admissible on any matter relevant to aggravation. ${ }^{14}$ Furthernore, he argued that even if psychiatric predictions are inaccurate, previous decisions have held that the uncertamty sur-

7. Id. at $767,631 \mathrm{P} .2 \mathrm{~d}$ at $466,175 \mathrm{Cal}$. Rptr. at 758.

8. Id. at 767-68, $631 \mathrm{P.2 \textrm {d }}$ at $466,175 \mathrm{Cal}$. Rptr. at 758.

9. Id. at 768-69, 631 P.2d at 466-67, 175 Cal. Rptr. at 758-59.

10. Id. at 771, 631 P.2d at 468-69, 175 Cal. Rptr. $760-61$.

11. Former section 190.3 was revised and strengthened by initiative in November 1978. Proposition 7 (codified at Cal. Penal Code $\S \S 190,190.1-.4$ (West Supp. 1982)). This initiative strengthened California's death penalty law by: 1) increasing the penalties for first and second degree murder, 2) expanding the list of special circumstances that, when found, require a sentence of death or life without possibility of parole, and 3) making a death sentence mandatory if the factinder determines that the aggravating circumstances outweigh the mitigating ones. See CALIfornia SeCretary of State, California Voters Pamphlet 32-33 (General Election, Nov. 7, 1978).

12. $29 \mathrm{Cal} .3 \mathrm{~d}$ at 772,631 P.2d at $469,175 \mathrm{Cal}$. Rptr. at 761.

13. Id. at $773-74,631$ P.2d at 470,175 Cal. Rptr. at 762 .

14. Id. at 777-78, $631 \mathrm{P.2d}$ at $472-73,175 \mathrm{Cal}$. Rptr. at $764-65$ (Richardson, J., concurring and dissenting). 
rounding expert opinions goes to the weight of the testimony rather than its admissibility, ${ }^{15}$ and any prejudicial impact of such expert testimony can be minimized by cross-examination and the introduction of opposing experts. ${ }^{16}$

\section{II}

\section{LEGAL BACKGROUND}

A revolution in capital sentencing standards began with Furman $\nu$. Georgia, ${ }^{17}$ which held that a capital sentencing scheme that gave the sentencing authority unlimited discretion was unconstitutional because it allowed imposition of an arbitrary and capricious death sentence. In Furman's aftermath, the California Supreine Court, in Rockwell v. Superior Court of Ventura County, ${ }^{18}$ struck down California's death penalty statutes as unconstitutional because they allowed the imposition of death sentences without consideration of initigating factors. ${ }^{19}$ To rectify the constitutional infirmity identified in Rockwell, the legislature enacted fornter Penal Code section 190.3, ${ }^{20}$ which provided that evidence "relevant to aggravation, initigation, and sentence" was admissible. $^{21}$ In addition, the section enumerated factors that the sentencing authority inight consider if relevant to determining the penalty. ${ }^{22}$

After Furman, in Jurek v. Texas ${ }^{23}$ the United States Supreme Court upheld the constitutionality of a Texas capital sentencing statute that required the trier of fact to determine the defendant's dangerousness. ${ }^{24}$ Although later Texas decisions admitted psychiatric predictions of dangerousness, ${ }^{25}$ the Court nade it clear in Estelle v. Smith ${ }^{26}$ that the Texas capital sentencing statute did "not require resort to medical experts."27 After noting that some members of the psychiatric comunu-

15. Id at 779-80, 631 P.2d at $473-74,175$ Cal. Rptr. at 765-66.

16. Id. at 780,631 P.2d at 474,175 Cal. Rptr. at 766.

17. 408 U.S. 238 (1972) (per curiam) (concurring opinions by Douglas, Brennan, Stewart, White \& Marshall, JJ.).

18. 18 Cal. 3d 420, 556 P.2d 1101, 134 Cal. Rptr. 650 (1976).

19. $18 \mathrm{Cal} .3 \mathrm{~d}$ at $438-45,556 \mathrm{P} .2 \mathrm{~d}$ at $1111-16,134 \mathrm{Cal}$. Rptr. at $660-65$.

20. See supra note 11.

21. 1977 Cal. Stat. ch. $316 \& 11$.

22. Id. Among the factors that the sentencing authority may consider are, inter alia: 1) circumstances of the crime, 2) presence or absence of criminal activity involving use of force, 3) age of the defendant, and 4) extenuating circumstances. These factors arc identical under both former $\S 190.3$ and the current $\S 190.3$.

23. 428 U.S. 262 (1976).

24. Id. at 274-76.

25. See, eg., Chambers v. State, 568 S.W.2d 313 (Tex. Crim. App. 1978) (en banc); Moore v. State, 542 S.W.2d 664 (Tex. Crim. App. 1976).

26. 451 U.S. 454 (1981).

27. Id. at 473 . 
nity questioned the reliability of expert predictions of dangerousness, ${ }^{28}$ the Smith Court held that if a defendant neitler put his neental state in issue nor had assistance of counsel to determine whetlier to do so, a psychiatric prediction of dangerousness was inadmissible during the penalty phase of a capital trial. Only where the defendant waived both his fifth amendment riglit against self-incrimination and his sixth amendment right to counsel before the psychiatric examination would the Court sanction admission of such evidence. ${ }^{29}$

Before Furman and its progeny, ${ }^{30}$ the California Supreme Court in People v. Hines ${ }^{31}$ upheld the admission of psychiatric predictions of dangerousness during the penalty pliase of a capital trial. ${ }^{32}$ To the extent that Hines is inconsistent with Murtishaw's ban on such predictions, Hines has been expressly overruled. Murtishaw thus continues the trend begun in Estelle v. Smith. Murtishaw's proscription, however, is even more restrictive than Smith's, because under Murtishaw admissibility turns on the underlying reliability of the expert prediction, rather than on compliance with procedural safeguards in obtaiming it.

\section{III}

ANALYSIS

\section{A. Expert Predictions of Dangerousness May Compromise the Integrity of Capital Sentencing}

\section{Need for Greater Reliability in Imposition of Death Sentence}

Central to the Murtishaw holding that psychiatric predictions of dangerousness are inadmissible is the court's recognition of the need for exacting standards of accuracy and reliability given the severity and finality of the death sentenee. As the United States Suprene Court acknowledged, death "is a different kind of punishment froin any other which nlay be imposed in this country." 33 In Woodson v. North Carolina ${ }^{34}$ which held that the inandatory imposition of the deatll penalty

28. Id. at 472 .

29. Id. at 466-71.

30. See, e.g., Lockett v. Ohio, 438 U.S. 586, 597-609 (1978) (plurality opinion) (defendant must be able to introduce evidence of mitigating circumstances); Gardner v. Florida, 430 U.S. 349, 355-62 (1977) (plurality opinion) (defendant must have opportunity to deny or explain information on which sentencing is based); Woodson v. North Carolina, 428 U.S. 280, 305 (1976) (plurality opimion) (mandatory imposition of death penalty unconstitutional); Gregg v. Georgia, 428 U.S. 153, 169 (1976) (plurality opinion) (death penalty not per se unconstitutional).

31. Hines' death sentence was the subject of two appeals. People v. Hines, 66 Cal. 2d 348, 425 P.2d 557, 57 Cal. Rptr. 757 (1967); People v. Hines, 61 Cal. 2d 164, 390 P.2d 398, 37 Cal. Rptr. 622 (1964).

32. See 66 Cal. 2d at 355, 425 P.2d at 561-62, 57 Cal. Rptr. at 761-62; 61 Cal. 2d at 173, 390 P.2d at 404-05, 37 Cal. Rptr. at 628-29.

33. Gardner v. Florida, 430 U.S. 349, 357 (1977) (plurality opinion).

34. 428 U.S. 280 (1976) (plurality opinion). 
is unconstitutional, the Court wrote: "the penalty of death is different from a sentence of imprisonment, however long ... . Because of that qualitative difference, there is a corresponding difference in the need for reliability in the determination that deatl is the appropriate punișlment in a specific case."35 In quoting the above passage froin Woodson, ${ }^{36}$ the Murtishaw court recognized this need and used it to distinguish capital cases from noncapital cases in which expert predictions of dangerousness inay be admissible. ${ }^{37}$ The court underscored this difference when it said that "[e]vidence which is barely reliable enough to justify a civil judgment or a limited commitment is not reliable enough to utilize in determining whether a man should be executed."38

\section{Inaccuracy of Expert Predictions of Dangerousness}

The preponderance of recent literature establishes that psychiatric predictions of violence are fundamentally of very low reliability, ${ }^{39}$ a fact also noted in a number of cases ${ }^{40}$ Furthermore, experts so regularly over-predict violence that their forecasts are more often wrong

35. Id. at 305 (plurality opinion). The Supreme Court agam recognized that there is an interest in rehability of capital sentencing in Gardner v. Florida, 430 U.S. at 359.

36. $29 \mathrm{Cal} .3 \mathrm{~d}$ at $771,631 \mathrm{P} .2 \mathrm{~d}$ at $468,175 \mathrm{Cal}$. Rptr. at 760.

37. See, e.g. People v. Henderson, 107 Cal. App. 3d 475, 483-84, 166 Cal. Rptr. 20, 25-26 (3d Dist. 1980).

38. 29 Cal. 3d at 771, 631 P.2d at 469,175 Cal. Rptr. at 761.

39. See Brief Amicus Curiae for the American Psychiatric Association, Estelle v. Smith, 451 U.S. 454 (1981) [hereinafter cited as Brief]; AMERICAN Psychological Association, Who is the Client? The Ethics of Psychological Intervention in the Criminal Justice System (J. Monalian ed. 1980); J. Monahan, The Clinical Prediction of Violent Behavior (1981); A. Stone, Mental Health and Law: A System in Transition (1976); $1 \mathrm{~J}$. Ziskin, Coping with Psychiatric and Psychological Testimony (3d ed. 1981), Cocozza \& Steadman, The Failure of Psychiatric Predictions of Dangerousness: Clear and Convincing Evidence, 29 RUTGERS L. Rev. 1084 (1976); Dershowitz, The Role of Psychiatry in the Sentencing Process, I INT'L J.L. \& Psychology 63 (1978); Diamond, The Psychiatric Prediction of Dangerousness, 123 U. PA. L. Rev. 439 (1974); Dix, The Death Penalty, "Dangerousness," Psychiatric Testimony, and Professional Ethies, 5 AM. J. CRIM. L. 151 (1977); Dix, Participation by Mental Health Professionals in Capital Murder Sentencing, 1 INT'L J. L. \& PsYchOLOGY 283 (1978); Ennis \& Litwack, Psychiatry and the Presumption of Expertise: Flipping Coins in the Courtroom, 62 CALIF. L. REv. 693 (1974); Morse, Crazy Behavior, Morals and Science: An Analysis of Mental Health Law, 51 S. CAL. L. Rev. 527 (1978).

40. Estelle v. Smith, 451 U.S. 454, 472 (1981) ("[S]ome in the psychiatric community are of the view that clinical predictions . . . are 'fundamentally of very low reliability' and psychiatrists possess no special qualifications for making such forecasts."); Addington v. Texas, 441 U.S. 418, 429 (1979) (predictions are fallible and uncertain); People v. Burnick, 14 Cal. 3d 306, 327, 535 P.2d 352, 366, 121 Cal. Rptr. 488, 502 (1975) (studies establish with "inupressive unanimity" the unreliability of psychiatric predictions); People v. Murtishaw, 29 Cal. 3d at 768, 631 P.2d at 466, 175 Cal. Rptr. at 758 ("Namerous studies have demonstrated the inaccuracy of attempts to forecast future violent behavior."). 
than right. ${ }^{41}$ Dr. Bernard Diamond, a well-known expert in law and psychiatry, has estimated that psychiatrists over-predict by a factor between ten and a hundredfold. ${ }^{42}$

Perhaps the most persuasive authority on the unrehability of psychiatric predictions of dangerousness comes from the psychiatric profession itself. In an amicus curiae brief to a 1981 United States Supreme Court case, Estelle v. Smith, ${ }^{43}$ the American Psychiatric Association cited the results of a task force study and argued that psychiatric predictions of dangerousness should be madmissible during the penalty phase of a capital trial because of their very low reliability. ${ }^{44}$ The Association attributed the lack of accuracy and reliability to the fact that "such judgments are predictions of rare or infrequent events." over, it argued, "[t]he professional literature uniformly establishes that such predictions are [unreliable] and that psychiatric testimony and expertise are irrelevant to such predictions." ${ }^{46}$ There is thus a clear consensus that psychiatric forecasts of long-term dangerousness are not rehable. ${ }^{47}$ Indeed, some take the position, and this Note argues, that psychiatrists' predictions of long-term dangerousness may not even meet the requirements for admission of expert testimony. ${ }^{48}$

\section{Prejudicial Impact}

The prejudicial impact of expert predictions of dangerousness is manifest when an impressively credentialed psychiatrist testifies to the effect that if the defendant is not sentenced to death, others are likely to die by his hand. ${ }^{49}$ Despite the proven unreliability of these predictions,

41. Cocozza \& Steadman, supra note 39, at 1101; Diamond, supra note 39, at 445; Ennis \& Litwack, supra note 39, at 714; Morse, supra note 39, at 598.

42. Diamond, supra note 39 , at 447.

43. 451 U.S. 454 (1981).

44. Brief, supra note 39 , at $10-17$.

45. Id. at 13 .

46. Id. at 8,15 .

47. The studies previously cited, supra note 39, pertain only to long-term predictions of dangerousness, which are the focus of the inquiry in capital cases. The American Psychiatric Association argues that only long-term predictions of dangerousness are fatally unreliable. Brief, supra note 39, at 11-12 n.5. The analysis in this Note refers only to these predictions.

Moreover, this Note does not argue for a prohibition of all psychiatric evidence. The ban on admission of psychiatric predictions during the penalty pliase would not "preclude the use of psychiatric testimony at the penalty phase to show defendant's present 'character, background, history, mental condition, and physical condition." " People v. Murtislaw, 29 Cal. 3d at 774 n.39, 631 P.2d at 470 n.39, 175 Cal. Rptr. at 762 n.39 (quoting former CAL. PENAL CoDE $\$ 190.3$, current version at CAL. PENAL CODE $\$ \S 190,190.1-.4$ (West Supp. 1982)); see also Brief, supra note 39 , at $11-12$ n.5.

48. See infra text accompanying notes 82-88.

49. See Smith v. Estelle, 602 F.2d 694, 697 (5th Cir. 1979) (psychiatric prediction "extremely damaging to the defendant"), affd, 451 U.S. 454 (1981). 
lay people tend to give them undue weight. ${ }^{\text {so }}$ Thus, because the sentencing authority is required to weigh aggravating and mitigating circumstances, it may incorrectly decide that aggravating circumstances outweigh mitigating ones and wrongly sentence a defendant to death. The Murtishaw court expressed the fear that a trier of fact, rather than making the difficult ethical determination, would rely upon an apparent scientific opmion. ${ }^{51}$ Other authorities, including the American Psychological Association, have expressed the same fear. ${ }^{52}$

Dangerousness is a vague, unscientific standard. ${ }^{53}$ A psychiatrist who testifies that a defendant is dangerous is not giving a scientific opmion, because the prediction indicates neither the specific harm the defendant is likely to cause nor the probability that the defendant will cause that harm. ${ }^{54}$ Instead, as the American Psychological Association has recognized, the expert is offering a unoral decision, a task generally considered within the province of the trier of fact. ${ }^{55}$ Yet, because the expert opimion creates the impression that it is an objective scientific finding, the trier of fact tends to rely heavily on it. ${ }^{56}$ Some commentators argue that the psychiatric opimion is so persuasive that the psychiatrist often has the power to decide the ultimate legal question. ${ }^{57}$ One study found that courts decided in accordance with the psychiatrist's prediction of dangerousness eighty-seven percent of the time. ${ }^{58}$ This finding is particularly disturbing in light of the evidence deinonstrating

50. Morse, supra note 39, at 626; cf. People v. Kelly, 17 Cal. 3d 24, 31-32, 549 P.2d 1240, 1244-45, 130 Cal. Rptr. 144, 148-49 (1976) (dangers of having scientific evidence presented by experts).

51. 29 Cal. 3d at 773,631 P.2d at 470,175 Cal. Rptr. at 762.

52. American Psychological Association, supra note 39, at 9, 11-15; Dix, Participation by Mental Health Professionals in Capital Murder Sentencing, supra note 39, at 307 (1978); Re. search into Violent Behavior: Overview and Sexual Assaults, Hearings Before the Subcomm. on Domestic and International Scientific Planning, Analysis and Cooperation of the House Comm. on Science and Technology, 95th Cong., 2d Sess. 175, 191 (1978) (testimony of John Monahan) [hereinafter cited as Hearings]. Monahan indicates that we continue to admit clinical predictions because they allow socially sensitive predictor variables (e.g., race, sex, economic status) to be conveyed in noncontroversial terminology. Id. at 189-91.

53. Morse, supra note 39, at 590-91. Any argument that dangerousness is an unconstitutionally vague standard appears to be foreclosed by Jurek $v$. Texas. There the Supreune Court notcd that the concept of future dangerousness is vague, but said that the prediction of "future criminal conduct" is essential to many decisions made im our criminal justice systein. 428 U.S. 262, 274-75 (1970) (pluratity opinion).

54. AMerican Psychological Association, supra note 39, at 9; Morse, supra note 39, at 591.

55. American Psychological Association, supra note 39, at 9.

56. See generally Morse, supra note 39, at 603 \& n.156.

57. Morse, A Preference for Liberty: The Case Against Involuntary Commitment of the Mencally Disordered, 70 CALIF. L. Rev. 54, 101 (1982). Soine cases have also addressed this point. See, eg., Washington v. United States, 390 F.2d 444 (D.C. Cir. 1967) (Bazelon, C.J.) (concerning dangers of psychiatrists deciding the case).

58. Cocozza \& Steadman, supra note 39 , at 1095. 
that psychiatric predictions are more often wrong than right. ${ }^{59}$

Thus, to admit these expert predictions of dangerousness is to ignore the clear potential for prejudice that threatens the integrity of sentencing procedures. In capital cases, where reliable sentencing procedures are inost important, courts should be particularly careful to avoid this danger.

\section{B. Unreliability of Expert Predictions Should Go to Admissibility in Capital Cases}

Although it would be consistent with past policy to hold that the uncertain accuracy of the testimony should go to its weight rather than to its admissibility, ${ }^{60}$ this section argues that Murtishaw's ban on the admission of predictions of dangerousness is justified. First, the Murtishaw court's two reasons for the ban are examined, and it is concluded that only one of thein is valid. Second, it is argued that regardless of any defects in the court's reasoning, its holding banning predictions of dangerousness is proper since defense counsel cannot protect the reliability of the sentencing process by minimizing the prejudicial effects of such predictions.

\section{The Court's Rationale}

The Murtishaw court rejected past policy by lolding expert predictions inadmissible for two reasons: 1) the need for greater reliability in capital sentencing, and 2) the marginal relevance of psychiatric predictions of dangerousness under California's death penalty statute. ${ }^{61}$ Of these two reasons, only the first can support Murtishaw's holding.

The court did not find expert predictions of dangerousness totally irrelevant to the determination that the sentencing autliority must make in a capital case. Evidence inay be irrelevant ${ }^{62}$ because it is 1) not nnaterial (i.e., the proposition it tends to prove is not properly in issue) or 2) not probative (i.e., it does not alter the probability that a material proposition is true or false). ${ }^{63}$ The court's language suggesting that evidence of dangerousness was immaterial to fornier section 190.3 should

59. See supra text accompanying notes $41-42$.

60. People v. Murtishaw, 29 Cal. 3d at 779-80, 631 P.2d at 474, 175 Cal. Rptr. at 766 (Richardson, J., concurring and dissenting). Cf. 29 AM. JuR. 2d Evidence § 251, at 301-02 (1967); Morse, supra note 39, at 625-26.

61. 29 Cal. 3d at 771-72, 631 P.2d at 468-69, 175 Cal. Rptr. at 760-61.

62. Evidence is relevant if it tends to prove a disputed fact of consequence to the action. CAL. Evid. CODE $\$ 210$ (West 1966).

63. James, Relevancy, Probability and the Law, 29 CALIF. L. REv. 689, 690-91 (1941). Evidence may be material but nonetheless irrelevant because of its lack of probative value. Id. at 693 . 
not be taken too literally, ${ }^{64}$ since the court subsequently ruled that a psychiatric prediction of dangerousness inay be admissible if it can be shown in a particular case to be reliable. ${ }^{65}$ If evidence of dangerousness were not material, psychiatric predictions would never be admissible regardless of their accuracy and reliability. ${ }^{66}$

Furthermore, the court could not have ruled that psychiatric predictions are irrelevant because they are so unreliable that they lack any probative value. If the court had so held, expert predictions would be inadmissible in all contexts. Yet the court cited with apparent approval their use im other types of cases, such as those involving mentally disordered sex offenders. ${ }^{67}$

Murtishaw's ban on admitting psychiatric evidence is therefore based solely on the need for greater reliability in capital sentencing. The court essentially conceded this point when it stated that evidence of dangerousness is arguably admissible, and hence relevant, under former section 190.3 as "a matter 'relevant to aggravation," " but that the prejudicial impact of such evidence far outweighs its probative value. ${ }^{68}$ When the possibility of prejudice is manifest and the probative value of expert predictions of dangerousness is questionable, the need for greater assurance that death is the appropriate sentence should mandate that the court err on the side of caution. ${ }^{69}$ This ground alone su-

64. $29 \mathrm{Cal} .3 \mathrm{~d}$ at $772,631 \mathrm{P} .2 \mathrm{~d}$ at $469,175 \mathrm{Cal}$. Rptr. at 761 . The penalty jury in a murder trial, however, is not directed to make specific findings as to dangerousness.

The Murtishaw court noted that in those legal proceedings in which expert predictions of dangerousness are admitted, a statute requires the trier of fact to determine dangerousness. See, e.g., Cal. Penal Code $\S 1026.2$ (West Supp. 1982) (restoration to sanity); Cal. Welf. \& INst. CoDE $\$ \S 5276,5300$ (West 1976) (commitment proceedings under the Lanterman-Petris-Short Act); CAL. Welf. \& lNST. CODE $\$ 6300$ (West 1972) (mentally disordered sex offender hearings).

65. $29 \mathrm{Cal} .3 \mathrm{~d}$ at 774,631 P.2d at 470, $175 \mathrm{Cal}$. Rptr. at 762.

66. This Note does not take the position that evidence of dangerousness is admissible under former section 190.3. Instead, it argues only that if dangerousness is to be considered, the need for greater reliability in capital sentencing slouild mandate that this determmation be made without resort to expert predictions. Indeed, the Murtishaw court noted that former section 190.3 might be unconstitutional if evidence of dangerousness were admissible. $29 \mathrm{Cal} .3 \mathrm{~d}$ at $773 \mathrm{n} .37,631 \mathrm{P} .2 \mathrm{~d}$ at 470 n.37, 175 Cal. Rptr. at 762 n.37; see Brief for Appellant at 240 (if evidence irrelevant to statutory criteria is admissible as a matter relevant to aggravation, then the statute is unconstitutional because it provides "illusory" guidance and thus allows arbitrary and capricious capital sentencing).

67. $29 \mathrm{Cal}$. 3d at 772,631 P.2d at 469, $175 \mathrm{Cal}$. Rptr. at 761 . See supra discussion at note 64 .

68. $29 \mathrm{Cal} .3 \mathrm{~d}$ at $773,631 \mathrm{P} .2 \mathrm{~d}$ at $470,175 \mathrm{Cal}$. Rptr. at 762.

69. The capital cases the dissent relies upon, with the exception of Jurek v. Texas, 428 U.S. 262 (1976), antedate the Supreme Court's recognition of the need for greater reliability and assurance that death is the appropriate sentence in capital cases. People v. Himes, $66 \mathrm{Cal} .2 \mathrm{~d} 348,425$ P.2d 557, 57 Cal. Rptr. 757 (1967); People v. Hines, 61 Cal. 2d 164, 390 P.2d 398, 37 Cal. Rptr. 622 (1964); People v. Bickley, 57 Cal. 2d 788, 372 P.2d 100, 22 Cal. Rptr. 340 (1962). Jurek, however, was decided the same day that the Court, in Woodson v. North Carolina, 428 U.S. 280 (1976), recognized the need for greater reliability in capital sentencing. Although under Jurek it is constitutional to consider dangerousness before sentencing a defendant to death, 428 U.S. at 274-76, Jurek in no way requires that a psychiatric prediction be used to make this determination. Estelle 
ports Murtishaw's prohibition on the admission of psychiatric forecasts of dangerousness during the penalty phase of a capital trial.

\section{Defense's Inability to Protect the Reliability of Capital Sentencing Procedures}

The dissent, arguing that the prejudicial nature of the testimony should go to its weight rather than its admissibility, maintained that any prejudice that might inhere in psychiatric predictions of dangerousness could be minimized by careful cross-examination of the expert and by the introduction of opposing testimony. ${ }^{70}$ This position suggests that defense counsel's skill can eliminate the prejudice threatening the integrity of capital sentencing. While there is some support for the proposition that the uncertain nature of the testimony should go only to its weight, ${ }^{71}$ the dissent's position should be rejected for three reasons. First, it is unlikely that defense counsel will be able to eliminate prejudice by cross-examination. Second, having to assess the reliability of psychiatric predictions will distract the trier of fact from determining the ultimate issue of wliether death is the appropriate punishment. Finally, the trier of fact can assess dangerousness without expert testimony.

\section{a. Eliminating Prejudice by Cross-Examination}

It is doubtful that defense counsel will be able to sufficiently minimize prejudice to the defendant by cross-examination, because attorneys are often unskilled at cross-examining psychiatrists ${ }^{72}$ and unfamiliar with the literature establishing the unreliability of such predictions. The Murtishaw and Estelle v. Smith trials demonstrate this weakness. Psychiatric predictions of defendant's long-tern propensity for violence were admitted during the penalty phase im both trials. ${ }^{73}$ In

v. Smith made it clear that this inquiry "is in no sense confined to the province of psychiatric experts." 451 U.S. 454,472 (1981).

The other cases relied upon by the dissent are not capital cases; hence, greater reliability in sentencing is not as necessary. See, e.g., Addington v. Texas, 441 U.S. 418 (1979) (civil commitment); Tarasoff v. Regents of Univ. of California, 17 Cal. 3d 425, 551 P.2d 334, 131 Cal. Rptr. 14 (1976) (civil suit); Brown v. Colm, 11 Cal. 3d 639, 522 P.2d 688, 114 Cal. Rptr. 128 (1974) (niedical unalpraetice); People v. Henderson, 107 Cal. App. 3d 475, 166 Cal. Rptr. 20 (3d Dist. 1980) (commitment of mentally disordered sex offender); Schnear v. Boldrey, 22 Cal. App. 3d 478, 99 Cal. Rptr. 404 (1st Dist. 1971) (medical inalpractice); see also People v. Murtislaw, 29 Cal. 3d at 77475 n.40, 631 P.2d at 471 n.40, 175 Cal. Rptr. at 763 n.40.

70. 29 Cal. 3d at 779-80, 631 P.2d at 474, 175 Cal. Rptr. at 766 (Richardson, J., concurring and dissenting).

71. See supra note 60 .

72. Morse, supra note 39, at 626.

73. People v. Murtislaw, 29 Cal. 3d 733, 767, 631 P.2d 446, 466, 175 Cal. Rptr. 738, 758 (1981), cert. denied, 50 U.S.L.W. 3591 (U.S. Jan. 25, 1981); Estelle v. Smith, 451 U.S. 454, 459-60 (1981). 
each, the defense attorneys failed to point out that such predictions are extremely unrehable. ${ }^{74}$ The Murtishaw defense counsel was so egregiously misinformed that the prosecution was able to claim in the presence of the jury that there were no statistics on the reliability of psychiatric predictions. ${ }^{75}$ The most cursory perusal of the literature would have proven the inaccuracy of this claim.

Arguably, defense counsel could demonstrate that expert predictions of dangerousness are inaccurate and thereby minimize prejudice to the defendant. In practice, however, this has not occurred.

\section{b. Distracting the Trier of Fact}

Even if prejudice could be minimized, the process by which defense counsel would counteract the prejudice would itself threaten the reliability of capital sentencing. Minimizing prejudice would probably require inore than skillful cross-examination. Psychiatric opinions are neither value-neutral ${ }^{76}$ nor unbiased. ${ }^{77}$ Instead, a psychiatrist may becoine an advocate for a party in subtle ways, ${ }^{78}$ a fact which makes it almost impossible to defend effectively against allegations by mental health experts without an expert of one's own. ${ }^{79}$ Yet even if the defense could find its own expert, for prejudice to be minimized the trier of fact would be required to: 1) assess the validity of psychiatric predictions, and 2) determine how much relative weight to give to each expert's testimony ${ }^{80}$ These tasks would increase the complexity of the sentencing authority's roles and pose a real danger of distracting the trier of fact from the ultimate issue of whether the defendant should live or die. ${ }^{81}$ Consequently, expert forecasts should be inadmissible because

74. See Brief for Defendant at 284, People v. Murtishaw, 29 Cal. 3d 733, 631 P.2d 446, 174 Cal. Rptr. 738 (1981), cert. denied, 50 U.S.L.W. 3591 (U.S. Jan. 25, 1982); United States Supreme Court Records and Briefs at A26-36, Estelle v. Smith, 451 U.S. 454 (1981).

75. Brief for Defendant at 284, People v. Murtishaw, 29 Cal. 3d 733, 631 P.2d 446, 175 Cal. Rptr. 738 (1981), cert. denied, 50 U.S.L.W. 3591 (U.S. Jan. 25, 1982).

76. $1 \mathrm{~J}$. ZiskIN, supra note 39, at 38; Diamond, The Psychiatrist as an Advocate, $1 \mathrm{~J}$. PsYcHIATRY \& L. 5 (1973); Morse, supra note 39, at 625.

77. 1 J. ZISKIN, supra note 39, at 37-38; Diamond, supra note 76, at 5.

78. Pollack, Psychiatric Consultation for the Court, in Medical \& Psychiatric Testimony IN CRIminal, CASES 177, 187-88 (1968).

79. Morse, supra note 39, at 625 . Given the documented tendency of psychiatrists to overpredict dangerousness, see supra text accompanying notes $41-42$, defendant may not be able to find an expert who will predict that he is not dangerous.

80. The United States Supreme Court has recognized that capital sentencing juries are often unfamiliar with sentencing and unskilled at evaluating evidence. Gregg v. Georgia, 428 U.S. 153, 192 (1976) (plurality opinion). The American Psychiatric Association made a similar argument in its amicus brief in Estelle v. Smith. Brief, supra note 39, at 12.

81. See Brief, supra note 39, at 16 (arguing that the use of psychiatric predictions of dangerousness can only "distort the fact finding process in a capital . . . trial"). Cf. Reed v. State, 283 Md. 374, 388, 391 A.2d 364, 371 (1978) (assessing the rehability of a scientific technique nay distract finder of fact froun central concern of deciding the merits of the case). 
attempts to minimize the resulting prejudice may themselves threaten the integrity of capital sentencing procedures.

\section{c. Expert Opinions Not Necessary for Factfinding}

Fimally, the sentencing authority in a capital case does not need expert testimony to consider the issue of dangerousness. Expert testinony is not adimissible if the subject is within the competence of the jury. ${ }^{82}$ Thus, psychiatric predictions should be admitted only if they will aid the trier of fact $\mathrm{m}$ its determinations. ${ }^{83}$ Yet there are many authorities who claim that psychiatric forecasts of dangerousness are so inaccurate that those who present them should not qualify as expert witnesses. ${ }^{84}$ The American Psychiatric Association is in accord with this view, mamtaining that "psychiatric expertise in the prediction of 'dangerousness' is not established." 85

If, as these authorities mamtam, psychiatrists are no more accurate than laypersons at predicting violence, ${ }^{86}$ excluding expert forecasts of dangerousness will deny the sentencing authority no relevant information. ${ }^{87}$ If the sentencing authority must assess the defendant's dangerousness, evidence such as a history of past violence can be presented just as effectively by lay witnesses. ${ }^{88}$

In sum, admittimg expert predictions on the assumption that defense counsel will minimize prejudice endangers the reliability of the capital sentencing determination. Either prejudice will not be eliminated or the life-or-death issue facing the sentencing authority may be

82. C. MCCoRmick, HandbooK of The LAW of EvidenCE, $\S 13$, at 29 (2d ed. 1972). This rule is codified in California at CAL. Evid. Code $\$ 801$ (West 1966).

83. CAL. Evid. Code $\S 801$ (a) (West 1966).

84. Brief, supra note 39, at 10-17; AMERICAN PsychologiCal Association, supra note 39, at 14; 1 J. ZISKIN, supra note 39, at 19; Diamond, supra note 39, at 451-52; Ennis \& Litwack, supra note 39, at 735-38. Because psychiatric predictions are inore often wroug than right, Ennis and Litwack argue that "[i]t is inconceivable that a judgment could be considered an 'expert' judgment when it is less accurate than the flip of a coin." Id. at 737.

One commentator maimtains that psychiatrists have little skill in assessing dangerousness beyond their own intuitive feelings. A. STONE, supra note 39, at 29 (citing Sturrup, Will This Man Be Dangerous?, in The Mentally Abnormal Offender 17 (1968)). The California Supreme Court has recognized that leading specialists in law and psychiatry urge that psychiatric predictions of long-terin dangerousness be inadmissible because of the absence of psychiatric expertise in this area. People v. Burnick, 14 Cal. 3d 306, 328 \& n.19, 535 P.2d 352, 366 \& n.19, 121 Cal. Rptr. 488, 502 \& n.19 (1975).

85. Brief, supra note 39 , at 15 . The Association noted that although psychiatric predictions appear to be "based on expert medical judgments, . . . no such expertise exists." Id. at 10 (citing american Psychiatric association, Task Force on Clinical aspects of the Violent InDIVIDUAL 33 (1974)).

86. Murel v. Baltimore City Criminal Court, 407 U.S. 355, 364-65 n.2 (1972) (Douglas, J., dissenting from denial of certiorari); see also Brief, supra note 39, at 16; Morse, supra note 39, at 602-03.

87. Brief, supra note 39 , at 17 .

88. Id. at 16 . 
obfuscated. There is no reason to endanger the reliability of capital sentencing procedures by admitting expert predictions of dangerousness that may prejudice the defendant's case when excluding these predictions will not diminish the accuracy of the determination of dangerousness.

\section{Lack of Guidance for Trial Courts}

In its reluctance to erect an absolute bar to the admission of psychiatric predictions of dangerousness, the Murtishaw court held that these predictions inay be admissible if they can be shown to be reliable and accurate in a particular case. ${ }^{89}$ Even if psychiatrists were better than laypersons at predicting dangerousness in either of the instances in which the court suggests that an expert prediction nay be admissible, these purported standards, as the dissent points out, "afford little or no guidance to the trial courts which inust apply them." "90

According to Murtishaw, psychiatric predictions during the penalty phase unay be admissible if a party "in a particular case . . . [can] show that a reliable prediction is possible." 91 The court suggested two instances in which this "inay be possible."92 First, "a reliable prediction might . . . be conceivable if the defendant had exhibited a long continued pattern of criminal violence such that any knowledgeable psychiatrist would anticipate future violence."93 Second, "[a] more rehable forecast, for example, might be possible if the psychiatrist has established a close, long-term relationship with defendant that gives him a greater understanding of defendant's behavior . . .."94 The court's use of equivocal language such as "might also be conceivable"95 and "for example might be possible" in indicates that these two instances are intended to be read only as suggestions. If a party in a particular case cannot show that an expert prediction of dangerousness will be more reliable, the prediction should be inadmissible.

This section explores probleins related to the court's lack of guidance in impleinenting these suggested exceptions. This Note contends that for neither of them will a party be able to show that an expert's prediction is nore reliable than a layperson's.

89. $29 \mathrm{Cal} .3 \mathrm{~d}$ at $774,631 \mathrm{P} .2 \mathrm{~d}$ at $470,175 \mathrm{Cal}$. Rptr. at 762.

90. Id. at 778, 631 P.2d at 473, 175 Cal. Rptr. at 765 (Richardson, J., concurring and dissenting).

91. $29 \mathrm{Cal} .3 \mathrm{~d}$ at $774,631 \mathrm{P} .2 \mathrm{~d}$ at $470,175 \mathrm{Cal}$. Rptr. at 762.

92. Id.

93. $I d$

94. Id.

95. $I d$.

96. Id. 


\section{Past Violence Exception}

Because the best predictor of future violent behavior is past violence, ${ }^{97}$ the Murtishaw court correctly reasoned that a more reliable prediction can be made when there is a history of violence. ${ }^{98}$ However, a prediction based on a history of violence would not necessarily be a good prediction; it would only be a better prediction. ${ }^{99}$ Moreover, because a psychiatric prediction based on a history of violence is no better than a lay forecast based on the same information, ${ }^{100}$ the sentencing authority can consider past violence to determine dangerousness with accuracy at least equal to an expert's prediction based on the same information. On this point the American Psychiatric Association agrees, taking the position that a psychiatric prediction of dangerousness based on knowledge of past violence "involves no inore 'expertise'-and certainly no more 'psychiatric expertise' than does that of the average nonexpert."101 The Association recommends that to the extent there is important evidence bearing on the issue of dangerousness-such as a history of violence-that evidence can be presented by lay witnesses who do not testify "with the mantle of professional expertise." 102 This practice would not diminish the accuracy of the jury's information, ${ }^{103}$ but it would remove the prejudice associated with expert testimony.

\section{Long-term Relationship}

The second of the court's suggested circumstances-a close longterm relationship between the psychiatrist and the defendant ${ }^{104}$-pro-

97. Hearings, supra note 52 , at 187.

98. $29 \mathrm{Cal}$. 3d at 774, 631 P.2d at 470-71, 631 Cal. Rptr. at 762-63; see also Hearings, supra note 52 , at 186 .

99. See, e.g., Hearings, supra note 52, at 187.

100. Brief, supra note 39 , at 14; Morse, supra note 39 , at 599-600.

101. Id.

102. Brief, supra note 39 , at $\mathbf{1 6 .}$

103. Id. at 17; see also Morse, supra note 39 , at 599-600 (lay predictions based on past conduct are as accurate as expert predictions).

104. Because of the psychotherapist-patient privilege, it is unlikely that a psychiatrist with a "close long-term relationship" with the defendant could ever testify for the prosecution. When a private psychotherapist-patient relationship exists, the patient may prevent the psychotherapist from disclosing confidential communications, CAL. Evid. CoDE $\$ 1014$ (West 1973), unless the patient-defendant has put his mental state in issue. CAL. EvID. CoDE $\$ 1016$ (West Supp. 1982). See also In re Lifshutz, 2 Cal. 3d 415, 467 P.2d 557, 85 Cal. Rptr. 829 (1970).

Even when a defendant has put his mental state in issue, the confidential privilege is waived only as to what the defendant specifically put in issue. Id. at 431-35, $467 \mathrm{P} .2 \mathrm{~d}$ at 566-70, $85 \mathrm{Cal}$. Rptr. at 839-44. Therefore, unless a defendant specifically put his dangerousness in issue, the psychotherapist-patient privilege would likely prevent a psychiatrist with a "close long-term relationship" with the defendant from testifying about the defendant's dangerousness. The Califorma Supreune Court, however, has created exceptions to statutory privileges. See Note, People v. Meredith: The Attorney-Client Privilege and the Criminal Defendant's Constitutional Rights, 70 CALIF. L. REv. 1048 (1982) (discussing exccption to the attorney-client privilege created in People v. Meredith, 29 Cal. 3d 682, 631 P.2d 46, 175 Cal. Rptr. 612 (1981)). 
vides no greater assurance of accurate forecasts of dangerousness than does the first. A psychiatrist's prediction will be no more reliable than that of a layman with whom the defendant has had a similar relationship. A leading authority in the field of law and psychiatry, Dr. Bernard Diamond, mamtains that the only additional information that would make a prediction of a psychiatrist with a close long-term relationship with the defendant more reliable would be knowledge of past violence. ${ }^{105}$ As already shown, predictions based on past violence do not require expertise for their accuracy. ${ }^{106}$ To the extent that the trier of fact must consider past violence known only to the expert, the psychiatrist can present the information in a nonexpert capacity.

Thus, in light of the evidence that psychiatric predictions of potential dangerousness are not more reliable or accurate than laypersons' predictions when there is either a "close long-term relationship" or a history of criminal violence, trial courts should not admit such predictions in either instance.

\section{IV}

\section{THE FRYE TEST}

The Murtishaw court leaves trial courts with almost no guidance to determine when a psychiatric prediction is reliable enough to be admissible. Instead of suggesting two vaguely defined exceptions, the court should have adopted the test for the admissibility of scientific evidence first enunciated in Frye v. United States. ${ }^{107}$ A means "for determining the underlying reliability of a new scientific technique," 108 it provides:

Just when a scientific principle or discovery crosses the line between the experimental and demonstrable stage is difficult to define. Somewhere in this twilight zone the evidential force of the principle must be recognized, and while the courts will go a long way in admitting cxpert testimony deduced from a well recognized scientific principle or discovery, the thing from which the deduction is inade inust be sufficiently estabished to have gained general acceptance in the particular field in which it belongs. ${ }^{109}$

Thus, evidence is admissible under the Frye test when it is generally regarded as reliable in the relevant scientific community. ${ }^{110}$ In the nearly sixty years since its introduction, the Frye test of "general ac-

105. Telephone interview with Dr. Bernard Diamond, Emeritus Professor of Law and Clinical Professor of Psychiatry, University of California, Berkeley (Jan. 4, 1982).

106. Brief, supra note 39, at 13-17; see supra text accompanying notes 97-103.

107. 293 F. 1013 (D.C. Cir. 1923).

108. People v. Kelly, 17 Cal. 3d 24, 30, 549 P.2d 1240, 1244, 130 Cal. Rptr. 144, 148 (1976).

109. 293 F. at 1014.

110. Reed v. State, 283 Md. 374, 381, 391 A.2d 364, 368 (1978). 
ceptance" has been adopted in most jurisdictions, ${ }^{11}$ including California. ${ }^{12}$ Among the areas to which California has applied tlie test are voice print analysis, ${ }^{113}$ polygraph tests, ${ }^{114}$ blood typing to determine paternity, ${ }^{115}$ and testimony induced by hypnosis. ${ }^{16}$

\section{A. Criticisms of Frye}

\section{Is Frye Too Conservative?}

Despite Frye's widespread acceptance, it lias been strongly criticized. McCormick, who rejects Frye in opposition to the great weight of authority, ${ }^{117}$ argues that the reliability of scientific evidence should go to its weight rather than its admissibility. ${ }^{118}$ Critics also urge that because Frye is conservative, it unduly prevents or delays admission of relevant evidence. ${ }^{19}$ There is truth to this criticism: Frye is conservative, and it does pose a substantial obstacle to the admission of new scientific principles. ${ }^{120}$ In People v. Kelly, ${ }^{121}$ however, the California Supreme Court rejected these criticisms and expressly held that Frye's conservatisn1 was its principal advantage. ${ }^{122}$ This Note has already argued at length that because of their prejudicial effects and inaccuracy, expert forecasts should be held inadmissible during the penalty pliase of a capital trial. When hunıan lives are at stake, a conservative test for admissibility is appropriate.

\section{Is Frye Appropriate for Expert Predictions of Dangerousness?}

Frye has generally been applied to new or experimental scientific techniques involving physical apparatus. ${ }^{123}$ An argument can be made

111. Id at 382,391 A.2d at 368. Reed lists a number of areas to which Frye lias been applied mcluding, inter alia, parafin tests, medical testimony regarding the cause of birth defects, breath analysis for intoxicatiou, truth serum imjections, blood tests, neutron activation analysis, gunshot residue tests, Nalline tests for detection of narcotics use, ink identification tests, and hypnotism. Id. at $383,391 \mathrm{~A} .2 \mathrm{~d}$ at 369.

112. People v. Kclly, 17 Cal. 3d 24, 30, 549 P.2d 1240, 1244, 130 Cal. Rptr. 144, 148 (1976).

113. Id.

114. People v. Wochnick, 98 Cal. App. 2d 124, 127-28, 219 P.2d 70, 72 (2d Dist. 1950).

115. Huntingdon v. Crowley, 64 Cal. 2d 647, 414 P.2d 382, 51 Cal. Rptr. 254 (1966).

116. People v. Shirley, 31 Cal. 3d 18, 641 P.2d 775, 181 Cal. Rptr. 243 (1982).

117. Reed v. State, 283 Md. 374, 386-87, 391 A.2d 364, 370 (1978).

118. C. MCCORMICK, supra note 82, \& 203, at 488-91; see also Gianelli, General Acceptance of Scientific Tests - Frye and Beyond, in SCIENTIFIC AND EXPERT EvideNCE 11-30 (E. Imwinkelreid 2d ed. 1981); Strong, Questions Affecting the Admissibility of Scientific Evidence, 1970 U. ILL. L.F. 1. But see Recent Developments, 64 CoRnell L. Rev. 875 (1979).

119. See U.S. v. Sample, 378 F. Supp. 44, 53 (1974); Reed v. State, 283 Md. 374, 384, 391 A.2d 364, 369 (1978); C. McCormicK, supra note 82, at 488-91.

120. People v. Kelly, 17 Cal. 3d 24, 30, 549 P.2d 1240, 1244, 130 Cal. Rptr. 144, 148 (1976).

121. Id. at 30-32, 549 P.2d at $1244-45,130$ Cal. Rptr. at 148-49.

122. Id. at 31, 549 P.2d at 1245, 130 Cal. Rptr. at 149 ("The primary advantage, lowever, of the Frye test hes in its essentially conservative nature.").

123. See, e.g., Frye v. U.S., 293 F. 1013, 1014 (D.C. Cir. 1923) (admissibility of results of lie 
that expert predictions of dangerousness are distimguishable from the scientific fields in which Frye has been applied because predictions of dangerousness are not new, and they do not involve any physical apparatus. Yet in People v. Shirley, ${ }^{124}$ the California Supreme Court rejected the contention that Frye applies only to evidence involving physical apparatus, ${ }^{125}$ holding instead that the test prohibited the admission of testimony induced by hypnosis. ${ }^{126}$

Psychiatric predictions of dangerousness also cannot be distimguished from areas in which Frye has been applied on the basis that such predictions no longer qualify as a new scientific technique. ${ }^{127}$ It carmot plausibly be maintained that the "newness" of scientific techmque is important for the purposes of applying Frye. The thrust of such an argument is that Frye is inapplicable to any scientific technique that has once been admitted even though new studies may prove that technique completely invalid.

This argument appears to have been rejected in People v. Kelly, ${ }^{128}$ where the court suggested that a technique once held admissible might later be found inadmissible should there be a change in the scientific commumity's attitudes. ${ }^{129}$ People v. Shirley also suggests that the applicability of the Frye test does not turn on how new the technique is. In Shirley, the court recognized that testimony induced by hypnosis has been admitted for twenty years, ${ }^{130}$ yet the court applied the Frye test. Even if the newness of the scientific technique were somehow important for purposes of applying the Frye test, it is difficult on that basis to find a distinction between testimony induced by liypnosis, to which the Frye test has been applied, and psychiatric predictions of dangerousness.

detector test); People v. Kelly, 17 Cal. 3d 24, 549 P.2d 1240, 130 Cal. Rptr. 144 (1976) (voice print analysis).

124. 31 Cal. 3d 18, 641 P.2d 775, 181 Cal. Rptr. 243 (1982).

125. Id. at 51-54, 641 P.2d at 794-95, 181 Cal. Rptr. at 262-64.

126. Id. at $66-67,641$ P.2d at 804,181 Cal. Rptr. at 272.

127. One California authority can be read as saying that Frye is not applicable where the production of the evidence in question is required by statute. Although in People v. Henderson, 107 Cal. App. 3d 475, 485-86, 166 Cal. Rptr. 20, 26-27 (3d. Dist. 1980), the court intimated that when a psychiatric prediction of dangerousness is required by statute, it is not new or experimental and thus Frye is inappropriate, the Murtishaw court declined to follow this suggestion. In a footnote, the court noted that it was not necessary to determine whether psyhiatric predictions of dangerousness inet the Frye test because they had already taken judicial notice of the unrehiability of such forecasts. 29 Cal. 3d at 769 n.32, 175 Cal. Rptr. at 759 n.32, 631 P.2d at 467 n.32. Thus, Murtishaw expressly left open the question of whether expert forecasts of violence should have to meet the Frye test. Of course, the Henderson rationale is not directly apposite here, where no statute requires the admission of a prediction of dangerousness.

128. 17 Cal. 3d 24, 549 P.2d 1240, 130 Cal. Rptr. 144 (1976).

129. Id. at 32,549 P.2d at 1245,130 Cal. Rptr. at 149.

130. $31 \mathrm{Cal} .3 d$ at 32, 641 P.2d at 782, 181 Cal. Rptr. at 250. 
California would not be the first jurisdiction to apply the Frye test to psychiatric evidence, ${ }^{131}$ nor is this Note alone in arguing that there is no distinction between fields in which Frye has been applied and expert predictions of dangerousness. ${ }^{132}$ For example, a dissenting opinion in a Texas capital case concluded that psychiatric predictions of dangerousness should be inadmissible during the penalty phase unless the Frye test is met. ${ }^{133}$ Dr. Bernard Diamond, whoin the California Supreme Court has recognized as a "nationally known specialist" in the field of law and psychiatry, ${ }^{134}$ would go even further and apply the Frye test to all psychiatric predictions of dangerousness, not just those inade during the penalty phase of a capital trial. ${ }^{135}$

\section{B. Advantages of Applying the Frye Test}

When the rehability of capital sentencing procedures is threatened, the court should err on the side of caution. Application of the Frye test is consistent with this conservative approach because it assures that the defendant will not face the danger of prejudice from a psychiatric pre-

131. Hughes v. Mathews, 576 F.2d 1250 (7th Cir. 1978) (holding a psychiatric diagnosis admissible because it met the Frye test).

In California, the Frye test was suggested as applicable to psychiatric testimony about current mental condition in People v. Spigno, 156 Cal. App. 2d 279, 288, 319 P.2d 458, 463 (2d Dist. 1957). There the conrt cited Frye and said that, before a psychologist is competent to measure the propensity of the defendant to commit the act clrarged, there should be a "slowing of at least a semblance of scientific acceptance of the psychologist's ability to fornulate a dependable conclusion . . . " 156 Cal. App. 2d at 288, 319 P.2d 458, 463.

132. Evidence based on lie detector tests lias been held madmissible because it does not meet the Frye test. Frye v. United States, 293 F. 1013 (D.C. Cir. 1923). It has been suggested that the rationale for preventing the admission of lie detector tests is equally applicable to psychiatric predictions of dangerousness. See $1 \mathrm{~J}$. ZISkIN, supra note 39, at 4; cf. Ennis \& Litwack, supra note 39, at 735-38 (reasons for excluding he detector evidence apply to psychiatric predictions).

133. State v. Smith, 534 S.W.2d at 906-07 (advance slieets) (ordered depublished), cited in Dix, The Death Penalty, "Dangerousness," Psychiatric Testimony, and Professional Ethics, supra note 39, at 165 n.17.

134. People v. Burnick, 14 Cal. 3d 306, 328 n.19, 535 P.2d 352, 366 n.19, 121 Cal. Rptr. 488, 502 n.19 (1975).

135. Teleplone interview with Dr. Bernard Diamond, Emeritus Professor of Law and Clinical Professor of Psychiatry, University of California, Berkeley (Jan. 4, 1982). The California Supreme Court gives a great deal of weight to Dr. Diamond's views. See People v. Shirley, 31 Cal. 3d at $63 \mathrm{n} .45,641$ P.2d at $802 \mathrm{n} .45,181 \mathrm{Cal}$. Rptr. at $271 \mathrm{n} .45$, where the court describes Dr. Diamond as one of the "most persuasive spokesmen for the relevant scientific community." Another commentator also suggests applying Frye to a broader range of psychiatric predictions of dangerousness. I J. Ziskin, supra note 39, at 3-5; accord Opening Brief for Appellant at 259-83, People v. Murtishaw, 29 Cal. 3d 733, 631 P.2d 446, 175 Cal. Rptr. 738 (1981), cert. denied, 50 U.S.L.W. 3591 (U.S. Jan. 25, 1982). This Note does not argue that Frye slould be applied to psychiatric predictions of dangerousness in all contexts in which a party's potential for future violence is at issue, bnt rather that no psychiatric forecast of dangerousness slrould be admitted in the penalty phase of a capital trial unless the forecast passes the Frye test. In a capital trial where there is a recognized need for greater reliability and assurance that death is the appropriate sentence, the rationale for using a conservative test like Frye applies a fortiori. 
diction unless there is substantial agreement in the scientific community that such predictions are reliable. Adoption of the Frye test would in three ways provide greater assurance that a deatl sentence would be appropriate in a particular case under current standards.

\section{Preventing Prejudice}

Frye would ensure that a prejudicial and unreliable prediction would not be mistakenly admitted. The threat to the reliability of capital sentencing posed by incorrect forecasts of violence has been shown in detail. The Murtishaw court further recognized that few matters could be inore prejudicial than an expert prediction of dangerousness. ${ }^{136}$ The Frye test is sensitive to this problem and mitigates the dangerous tendency of lay jurors to give undue weight to scientific evidence. ${ }^{137}$

In People v. Kelly, where the California Supreme Court applied Frye to voice print analysis, it warned that "lay jurors tend to give considerable weight to 'scientific' evidence when presented by 'experts' with impressive credentials. . . . [S]cientific proof may in some instances assume a posture of nyystic infallibility in the eyes of the jury ...."138 California courts have justified applying Frye on the grounds that particular care should be taken to avoid this danger in a criminal case ${ }^{139}$ because of the possibility of "substantial unfairness to a defendant . . . [resulting] froin ill conceived techniques with which the trier of fact is not technically equipped to cope."140 This justification for Frye applies a fortiori where a person's life is at stake.

\section{Determination by the Relevant Scientific Community}

If the Frye test were adopted, psychiatric predictions would not be admissible now because they are not generally accepted as reliable in the relevant scientific community. ${ }^{141}$ As the Kelly court recognized, however, a scientific technique that fails to pass Frye is not forever foreclosed froin being admitted. ${ }^{142}$ If the scientific community later came to accept psychiatric predictions of dangerousness as reliable,

136. 29 Cal. $3 d$ at 773,631 P.2d at 470,175 Cal. Rptr. at 762 .

137. People v. Shirley, 31 Cal. 3d at 53-54, 641 P.2d at 796, 181 Cal. Rptr. at 264 (quoting People v. Diggs, 112 Cal. App. 3d 522, 531, 169 Cal. Rptr. 386, 391 (1st Dist. 1980)).

138. 17 Cal. 3d at 31-32, 549 P.2d at 1245, 130 Cal. Rptr. at 149.

139. People v. Law, 40 Cal. App. 3d 69, 75, 114 Cal. Rptr. 708, 712 (5th Dist. 1974); see People v. Kelly, 17 Cal. 3d at 32, 549 P.2d at 1245, 130 Cal. Rptr. at 149.

140. People v. Law, 40 Cal. App. 3d at 75, 114 Cal. Rptr. at 712.

141. The American Psychiatric Association, the American Psychological Association, and the literature are in substantial agreement that expert predictions of dangerousuess are unreliable; see authorities cited supra note 39.

142. $17 \mathrm{Cal} .3 \mathrm{~d}$ at 41,549 P.2d at $1251,130 \mathrm{Cal}$. Rptr. at 155 . 
such predictions would then pass the Frye test and be admissible. This flexibility would comport with the Murtishaw court's reluctance to erect an absolute bar to the admission of psychiatric predictions.

Moreover, under the Frye test the reliability of a given scientific method is assessed by the body most qualified to make such a determination; ${ }^{143}$ thus, Frye provides the best guarantee that an unreliable psychiatric prediction will not be admitted. Absent Frye, eacli trial court is left to decide for itself whether a prediction is reliable enough to be admissible in a particular case. Ultimately, the reliability of a scientific technique should be determined by experiments and studies, ${ }^{144}$ solnething that courts are ill equipped to do. ${ }^{145}$ The not unlikely result of determining the reliability of psychiatric predictions on a case by case basis is that a trial court will mistakenly admit an unreliable prediction. As discussed above, inaccurate predictions will likely be admitted if Murtishaw's two "suggested exceptions" guide the trial court. Applying the Frye test avoids this problem by relieving courts of the responsibility for determining the reliability of the scientific technique. Under Frye, the court's inquiry is not whether expert forecasts are reliable as a matter of scientific fact, but only whetlier they have been generally accepted as rehable by the relevant scientific community. ${ }^{146}$

\section{Uniformity of Decision}

Finally, one of Frye's virtues is that, in determining reliability by general acceptance in the scientific community, it promotes a "degree of uniformity of decision." 147 Without Frye, different courts may reach different conclusions about whether psychiatric predictions of dangerousness are reliable enough to be admissible. In view of the prejudice caused by psychiatric predictions of dangerousness, a sentence of death could turn on whether the court found such a prediction admissible. Thus, defendants in substantially similar situations might receive different sentences depending on the trier of fact's view of the reliability of a psychiatric prediction. Not only would capital sentencing procedures thus be rendered unreliable, but a capital sentencing scheme that permitted this variation might be seen as so arbitrary and capricious as to violate the United States Constitution. ${ }^{148}$ The uniformity of decision that Frye promotes would avoid the danger of arbitrary and capricious sentencing to the extent it is caused by eacl court's determining on its

143. Id. at 31,549 P.2d at 1244,130 Cal. Rptr. at 148 .

144. See Reed v. State, 283 Md. 374, 387, 391 A.2d 364, 371 (1978).

145. Id.

146. People v. Shirley, 31 Cal. 3d at 55, 641 P.2d at 797, 181 Cal. Rptr. at 265.

147. People v. Kelly, 17 Cal. 3d at 31, 549 P.2d at 1245, 130 Cal. Rptr. at 149.

148. Gregg v. Georgia, 428 U.S. 153, 188 (1975) (plurality opinion). 
own whether expert predictions of dangerousness are relable enough to be admissible.

\section{CONCLUSION}

This Note argues that the Murtishaw court was correct in holding that the admission of psychiatric predictions of dangerousness during the penalty phase of a capital trial constituted reversible error as to penalty. Such predictions are so unrehable and prejudicial that their admission lessens the rehability and assurance that the death sentence is warranted under current standards. The court, however, in suggestimg that an expert prediction of dangerousness may be admissible if a party can establish that the forecast is rehable in a particular case, leaves trial courts with hittle guidance. Instead, the court should have held that such predictions are imadmissible until they can meet the Frye test for the admissibility of scientific evidence, which requires that such evidence have gained general acceptance in the relevant scientific community.

Because of the severity of the sanction, the strongest argument against admitting expert predictions of dangerousness can be made for capital cases. Yet many of the dangers created by using such expert predictions in capital sentencing procedures are present whenever these notoriously unreliable forecasts are admitted. This suggests that if expert predictions of dangerousness are not inadmissible in all contexts, they should at least be viewed with extreme skepticism.

Steven M. Garrett*

* B.A. 1979, Stanford University; third year student, Boalt Hall School of Law, University of California, Berkeley. 